\title{
Host-controlled Restriction Mutants of Salmonella typhimurium
}

\author{
By ANNE M. COLSON, C. COLSON AND ALINE VAN PEL \\ Laboratoire de Cytogénétique, Institut Carnoy, \\ Université de Louvain, 24, Vaartstraat, Louvain, Belgium \\ (Accepted for publication 27 May 1969)

\begin{abstract}
SUMMARY
Forty-eight independent restriction-deficient mutations of Salmonella typhimurium LT 2 were isolated by using selective and non-selective methods. With phage $\mathbf{P} 22$ it was shown that some mutations affected the restriction capacity only, while others affected both restriction and modification. The host-restriction of $S$. typhimurium decreased the recovery of F-lac ${ }^{+}$infected cells and decreased the yield of recombinants in bacterial mating and in phage $\mathrm{P}$ 22-mediated transduction.
\end{abstract}

\section{INTRODUCTION}

Host specificity is a process by which bacterial cells control the acceptance of foreign DNA. Two strain-specific mechanisms are involved in the achievement of this control. (I) The DNA synthesized within the cell can be altered in a non-inheritable fashion (modification). In at least one case this modification has been shown to be the methylation of a DNA base (Arber \& Smith, I966). (2) Upon entry into the cell, foreign DNA which does not carry the appropriate modification can be rapidly degraded (restriction). The primary step in this degradation is due to a specific endonuclease which causes a discrete number of double-chain scissions in the DNA (Meselson \& Yuan, 1968). Strain-specific sites, probably base sequences, along the DNA, must be present and recognized before either restriction or modification can be exercised (Arber \& Kühnlein, 1967).

Most of our present understanding of host specificity comes from genetical and biochemical studies in Escherichia coli in which differences in host specificity between strains were described several years ago and in which it was possible to isolate and study host specificity deficient mutants (review: Arber \& Linn, 1969). Salmonella typhimurium LT 2 and LT 7 strains are extensively used in genetical studies, yet no difference in host specificity has been described between them. The existence in $S$. typhimurium of a barrier to the acceptance of DNA carrying $E$. coli host specificity was nevertheless suggested by some incidental observations (Zinder, 1960; Miyake, I 962). Furthermore, it has been shown that the fertility ( fer) mutation in S. typhimurium results in the loss of previously undetected host restriction towards the DNA of $E$. coli (Colson \& Colson, I967; Okada, Watanabe \& Miyake, I968). The key observation in these studies was that the restriction which affects $E$. coli DNA also affects phage P 22 DNA. Most fer mutants lose both the restriction and the modification functions, and lysates of phage $P 22$ produced by them form plaques less efficiently $\left(10^{-4}\right)$ when plated on $S$. typhimurium LT 7 or LT 2 than on the fer mutants themselves. 
The experiments presented in this paper constitute the first step in an investigation of the genetic control of the host specificity that was revealed in Salmonella typhimurium by the isolation of fer mutants. We describe the isolation and the phenotypic characterization of a collection of restriction deficient mutants from $S$. typhimurium strain LT 2.

\section{METHODS}

Bacteria. Salmonella typhimurium strains LT 7 and LT 7 mut (carrying a mutator gene) were obtained from G. G. Meynell (Lister Institute, London). Restriction deficient mutants of these strains were described previously (Colson \& Colson, 1967). S. typhimurium LT 2:proC 90 and proC 110 were obtained from H. O. Smith; SR 305 HfrA hisD 23 gal-50 and SB 106 ile-405 rha-46I leu-I003 proA 46 purC 7 str-r from P. Hartman; SA 534 HfrK $4 \operatorname{ser} A 1_{3}$, SA I95 proAB 47 purE 66, and $\arg D 6$ from $\mathrm{K}$. Sanderson; SL 1027 met $A$ metE $\operatorname{trp} B$ xyl str-r from B. Stocker.

Escherichia coli K I2; w I655 met lac F-lac ${ }^{+}$; a derivative of $\mathrm{C} 600$ lacking the $\mathrm{K}$ host specificity (Colson, Glover, Symonds \& Stacey, I965). E. coli в: a derivative of BC 25I lacking the B host specificity (Glover \& Colson, I969).

Bacteriophages. Phage $\mathbf{P} 22$ wild type was obtained from P. Fredericq. A $c 2$ mutant was provided by G. G. Meynell.P 22 int-II, lacking a function necessary for the integration of the prophage into the bacterial chromosome (Smith \& Levine, 1967) was donated by H. O. Smith.

Media. Nutrient broth contained Difco Bacto Tryptone, Io g.; NaCl, 8 g.; distilled water, I 1 . Nutrient agar was nutrient broth solidified with $\mathrm{I} \cdot 5 \%(\mathrm{w} / \mathrm{v})$ Difco Bacto agar. Phage agar was broth containing I \% (w/v) Difco Bacto agar and was used as bottom layer for phage assay in soft agar overlays. Soft agar was $0.6 \%(w / v)$ Difco Bacto agar in distilled water. EMB lactose agar, was as Arber \& Morse (1965). Minimal medium (g./1.): $\mathrm{NH}_{4} \mathrm{Cl}, 5 ; \mathrm{NH}_{4} \mathrm{NO}_{3}, \mathrm{I} ; \mathrm{Na}_{2} \mathrm{SO}_{4}, 2 ; \mathrm{K}_{2} \mathrm{HPO}_{4}, 3 ; \mathrm{KH}_{2} \mathrm{PO}_{4}, \mathrm{I}$; $\mathrm{MgSO}_{4} .7 \mathrm{H}_{2} \mathrm{O}$, $0 \cdot \mathrm{I}$; this medium was solidified with $\mathrm{I} \cdot 5 \%(\mathrm{w} / \mathrm{v})$ Difco Bacto agar and supplemented with $0.02 \mathrm{~g} . / 1$. of appropriate L-amino acids or adenine when necessary. Dilution buffer contained (g./1.): $\mathrm{KH}_{2} \mathrm{PO}_{4}, 3 ; \mathrm{Na}_{2} \mathrm{HPO}_{4}, 7 ; \mathrm{NaCl}, 4 ; \mathrm{MgSO}_{4} \cdot 7 \mathrm{H}_{2} \mathrm{O}$, $0 \cdot 2$.

Mutagenic treatment. Exponentially growing broth cultures were incubated at $37^{\circ}$ for $25 \mathrm{~min}$. in the presence of $N^{\prime}-N$-methyl- $N$-nitrosoguanidine (NTG) $30 \mu \mathrm{g} . / \mathrm{ml}$. NTG was removed by twice washing in buffer. The cells were then diluted $I / 100$ in fresh broth and incubated to allow expression of the mutations.

Terminology. According to Arber \& Linn (1969) the following terminology for host specificity will be used. The host specificity system of Salmonella typhimurium LT 7 and LT 2 will be noted as ' $L T$ '. The phenotypes will be characterized as $r_{\mathrm{LT}}$ for restriction and $m_{L T}$ for modification, with the superscript plus or minus. Thus $r_{\mathbf{L T}}^{+} m_{L_{T T}}^{+}$characterizes wild type, while $\mathrm{r}_{\mathrm{LT}}^{-} \mathrm{m}_{\mathrm{LT}}^{+}$and $\mathrm{r}_{\mathrm{LT}}^{-} \mathrm{m}_{\mathrm{LT}}^{-}$will indicate respectively strains lacking the LT restriction, and both the LT restriction and the LT modification. The presence or the absence of the LT modification on phage $P 22$ will be specified by the notation for the LT specificity preceded by a point. Thus P 22. LT characterizes phage P 22 carrying the LT modification, while $P$ 22.0 indicates phage $P 22$ lacking any detectable modification. 
RESULTS

\section{Isolation of restriction--deficient mutants}

Stocks of phage $\mathrm{P} 22$ c 2 lacking the LT modification ( $\mathbf{P} 22 c 2.0$ ) were obtained on a previously isolated fer mutant of Salmonella typhimurium LT7 (Colson \& Colson, 1967) and on an $\arg D$ mutant of strain LT 2 that was found to lack both restriction and modification. A wide variation in efficiency of plating (e.o.p.) was observed when these phage stocks were plated on NTG-treated cultures of LT 2. On most cultures the phage formed plaques at a higher frequency than on control cultures. It was logical to assume that the increase in successful infections originated from infection of restriction-deficient mutants, thus raising the e.o.p. of $\mathbf{P} 22.0$ significatively higher than that obtained under normal condition of restriction. This test was therefore repeated on a large number of independent NTG-treated cultures from several strains of LT 2 to assess the efficiency of the mutagenic treatment and to discriminate those cultures which after further selection could be expected to yield mutants. An increase in e.o.p. from $\mathrm{IO}^{-4}$ to more than $1 \mathrm{O}^{-3}$ was commonly observed, indicating the presence of more than $0.1 \%$ of accepting cells. Such powerful mutagenesis allowed simple methods to be used with success for the isolation of the mutants. About $\mathrm{I} \times 10^{3}$ cells from the NTG-treated cultures were spread on nutrient agar plates together with $\mathrm{I} \times \mathrm{IO}^{5}$ particles of $\mathbf{P} 22 c 2.0$. After overnight incubation, the plates were screened for the presence of colonies showing phage infection at their edges. Such colonies were picked, restreaked and tested for their restriction phenotype. About one-third of them were found to be $\mathrm{r}_{\mathrm{LT}}^{-}$( 40 out of $\mathrm{I} 26$ tested). Most mutants were isolated by this method, but two other selective methods were used.

It was shown that $F-l a c$ is subject to host-restriction when transferred from Escherichia coli to Salmonella typhimurium (Colson \& Colson, 1967). Transfer could therefore select accepting cells, as does the transfer of an R factor (Okada \& Watanabe, I 968). Samples of mutagen-treated cultures of $S$. typhimurium were spread on minimal lactose plates together with samples of exponentially growing $E$. coli W I 655 F-lac ${ }^{+}$met. Contra-selection of the donor was achieved by omitting methionine from the medium and by the presence of streptomycin when a met recipient strain was used (SL IO27). Some $\mathbf{r}_{\mathrm{LT}}^{-}$were found among the $l a c^{+}$colonies, but only at a frequency of $10 \%$ (6 of 68 tested).

Transduction of bacterial markers from a strain lacking modification was also used as a method to select $r_{L T}^{-}$mutants in the recipient. Preliminary experiments had revealed that the frequency of transduction by $\mathrm{P} 22$ was very poor in LT 7 when the transducing lysate was grown on $\mathrm{LT} 7 \mathrm{r}_{\mathrm{LT}}^{-} \mathrm{m}_{\mathrm{LT}}^{-}$(Colson \& D'Aout, unpublished). However, the fact that most $\mathbf{P} 22$ transduced clones are immune to $\mathbf{P} 22$ under the conditions used meant that scoring for restriction with $\mathbf{P} 22.0$ was impossible. This difficulty was overcome with a P 22 int mutant (Smith \& Levine, 1967). Such phage mutants are deficient in the integration function and cannot lysogenize by themselves. Lysogenic strains for $\mathrm{P} 22$ int can nevertheless be obtained by complementation between int and $c$ mutants. After induction, such lysogenic cultures produce highly defective lysates which transduce some bacterial markers (proC, purE) at an abnormally high frequency (Smith, 1968). LT $2 \arg D 6 \mathrm{r}_{\mathrm{LT}}^{-} \mathrm{m}_{\mathrm{LT}}^{-}$was lysogenized with $\mathrm{P} 22$ int-II and induced according to the methods of Smith (1968). The lysate was utilized to transduce proC $^{+}$and purE ${ }^{+}$to NTG-treated strains. Most transduced clones were 
found to be $\mathrm{P}$ 22-sensitive after one restreaking. Only a few of them (5 of I95 tested) were found to be restriction-deficient.

To ensure that all the mutants for further studies originated from independent mutational events only one $\mathrm{r}_{\mathrm{LT}}^{-}$clone was kept from each NTG treated culture. A total of 48 independent restriction-deficient mutants were isolated in LT 2 strains, 37 were obtained from direct screening, 6 after F-lac ${ }^{+}$infection and 5 by P 22 int.o transduction.

Table I. Host specificity phenotypes among 48 restriction-deficient mutants of Salmonella typhimurium

\begin{tabular}{|c|c|c|c|c|}
\hline \multirow[b]{2}{*}{ Strain } & \multicolumn{4}{|c|}{ No. of mutants with phenotype } \\
\hline & $\mathrm{r}_{\mathrm{LT}}^{-} \mathrm{m}_{\mathrm{LT}}^{-}$ & $\mathrm{r}_{\mathbf{L T}}^{-} \mathrm{m}_{\mathbf{L T}}^{+}$ & $\mathrm{r}_{\mathbf{L T}}^{ \pm} \mathrm{m}_{\mathrm{LT}}^{+}$ & $\mathrm{r}_{\mathrm{LT} T} \mathrm{~m}_{\mathrm{LT}}^{ \pm}$ \\
\hline SR 305 & 0 & I & 0 & I \\
\hline SA 534 & 3 & I & 0 & 5 \\
\hline SB 106 & 0 & 2 & 0 & 0 \\
\hline SA I95 & 2 & 2 & I & 4 \\
\hline SL 1027 & I & I & o & 3 \\
\hline proC 90 & 9 & 3 & o & 4 \\
\hline procilo & 3 & 0 & 0 & 2 \\
\hline Total & I 8 & 10 & I & 19 \\
\hline
\end{tabular}

Restriction ability was determined by plating samples of serial dilutions of $P 22.0$ with samples of exponentially growing cultures of the mutants. $\mathrm{r}_{\overrightarrow{\mathrm{LT}}}^{\overrightarrow{ }}$ corresponds to an e.o.p. of about $\mathrm{I} \cdot 0 ; \mathrm{r}_{\mathrm{LT}}^{ \pm}$to an e.o.p. of $10^{-1}$. Modification ability was determined by picking and resuspending phage from a single plaque on each mutant and plating serial dilutions of it on the mutant itself and on wild type LT 2. Mutants producing phage with the same e.o.p. on both strains were classified as $\mathrm{m}_{\mathrm{LT}}^{+}$, those from which the phage was restricted about $10^{-4}$ were scored as $\mathrm{m}_{\mathrm{LT}}^{-}$, those producing phage that was restricted $1 \mathrm{IO}^{-1}$ to $\mathrm{IO}^{-3}$ were scored as $\mathrm{m}_{\mathrm{LT}}^{ \pm}$.

\section{Phenotypic classes of restriction-deficient mutants}

Several host specificity phenotypes were observed among the restriction-deficient mutants. These phenotypic classes were distinguished by the degrees of acceptance of P 22.0 and from the subsequent e.o.p. of the phage produced by the mutants when plated on wild-type hosts. Table I summarizes the frequency of these classes among the various strains. A weak restriction was found in only one mutant $\left(\mathrm{r}_{\mathrm{LT}}^{ \pm} \mathrm{m}_{\mathrm{LT}}^{+}\right)$in which P 22.0 was restricted about Io-fold. Among the others some had completely lost the ability to confer the modification $\left(\mathrm{r}_{\mathrm{LT}}^{-} \mathrm{m}_{\mathrm{LT}}^{-}\right)$while others produced fully modified P $22\left(\mathrm{r}_{\mathrm{LT}}^{-} \mathrm{m}_{\mathrm{LT}}^{+}\right)$. Quite frequently intermediate abilities to modify were observed. Phage produced by these mutants plated on wild-type hosts with an e.o.p. between $10^{-1}$ and $\mathrm{IO}^{-3}$. These phenotypes intermediate for modification were classified as $\mathrm{r}_{\mathrm{LT}}^{-} \mathrm{m}_{\mathrm{LT}}^{ \pm}$. Table 2 shows the e.o.p. of P 22 on LT 2 and on some of its $\mathrm{r}_{\mathrm{LT}}^{-}$mutants and also on LT 7 and on some LT 7 mutants isolated previously (Colson \& Colson, 1967). These results confirm that there is no difference in host specificity between LT 2 and LT 7. When phage was grown on wild type LT 2 its e.o.p. on LT 7 was as good as on LT 2, and vice versa. Similarly, when the phage was grown on a $\mathrm{m}_{\mathrm{LT}}^{-}$mutant of either LT 2 or LT 7 its e.o.p. was decreased by a similar factor on both wild-type strains. The decreased restriction which is commonly observed in LT 7 mut is caused by a high frequency of mutator-induced $\mathrm{r}_{\mathrm{LT}}^{-}$mutants in the population. 


\section{Host restriction of bacterial DNA}

Host specificity mutants were isolated in several genetically marked strains and in Hfr donor strains. It was therefore possible to investigate the incidence of restriction in bacterial matings and in transduction. Pairs of otherwise isogenic $r_{\mathrm{LT}}^{+}$and $r_{\mathrm{LT}}^{-}$ strains were used as recipients in conjugation experiments with two Hfr strains, one of which carried a mutation leading to the $\mathrm{r}_{\mathrm{LT}}^{-} \mathrm{m}_{\mathrm{LT}}^{-}$phenotype. Within each set of four crosses, restriction of donor DNA could occur in only one mating pair (Hfr

Table 2. Efficiencies of plating of P 22 on $L T 2, L T 7$ and $r_{\mathrm{LT}}^{-}$mutants of Salmonella typhimurium

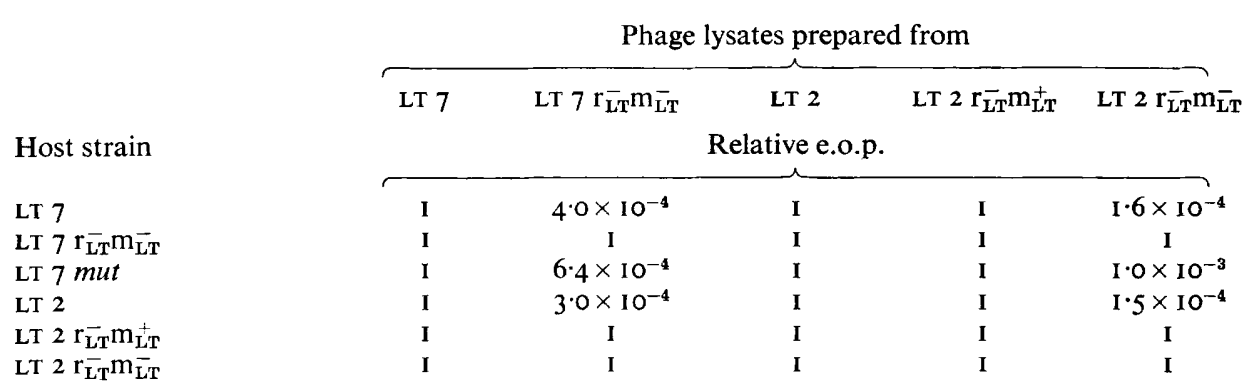

Phage from a single plaque of $\mathbf{P} 22 \mathrm{c} 2$ grown on each host strain was used to inoculate the same host in soft agar overlays. After incubation, the overlays were harvested, shaken with chloroform and buffer and cleared by centrifugation. The lysates were suitably diluted and plated in overlays with exponentially growing cultures of each strain. The e.o.p. values given are based on counts of several hundred plaques. Differences in titre of less than $20 \%$ were not regarded as significant.

\section{Table 3. Host restriction in bacterial matings in Salmonella typhimurium}

\begin{tabular}{|c|c|c|c|c|}
\hline \multirow[b]{2}{*}{ Recipient strain } & \multirow{2}{*}{$\begin{array}{l}\text { Selected } \\
\text { marker }\end{array}$} & \multicolumn{2}{|c|}{$\begin{array}{l}\text { No. of recombinants } \\
\text { per donor cell }\end{array}$} & \multirow{2}{*}{$\begin{array}{c}\text { Corrected } \\
\text { restriction value }\end{array}$} \\
\hline & & $\mathrm{r}_{\mathbf{L} \mathbf{T}}^{+} \mathrm{m}_{\mathbf{L} \mathbf{T}}^{+}$ & $\mathrm{r}_{\mathbf{L T}}^{-} \mathrm{m}_{\mathbf{L T}}^{-}$ & \\
\hline SB 106 & $\operatorname{proA}^{+}$ & $2.4 \times 10^{-3}$ & $2.4 \times 10^{-4}$ & \multirow{2}{*}{$5.1 \times 10^{-2}$} \\
\hline SB $106 \mathrm{r}_{\mathrm{LT}}^{-} \mathrm{m}_{\mathrm{LT}}^{+}$ & $\operatorname{proA}^{+}$ & $4.5 \times 10^{-3}$ & $\left.2 \cdot 3 \times 10^{-3}\right\}$ & \\
\hline SB 106 & $\mathrm{leu}^{+}$ & $4.0 \times 10^{-3}$ & $\left.3.0 \times 10^{-4}\right\}$ & \multirow{2}{*}{$4^{\circ} \mathrm{I} \times 10^{-2}$} \\
\hline $\mathrm{SB} 106 \mathrm{r}_{\mathrm{LT}}^{-} \mathrm{m}_{\mathrm{LT}}^{+}$ & $\mathrm{leu}^{+}$ & $7.4 \times 10^{-3}$ & $\left.4.0 \times 10^{-3}\right\}$ & \\
\hline proC 90 & $\operatorname{proC}^{+}$ & $5.0 \times 10^{-4}$ & $\left.2.9 \times 10^{-5}\right\}$ & \multirow{2}{*}{$\mathrm{I} \cdot 5 \times \mathrm{IO}^{-1}$} \\
\hline proc $90 \mathrm{r}_{\mathrm{LT}}^{-} \mathrm{m}_{\mathrm{LT}}^{-}$ & pro $C^{+}$ & $8.0 \times 10^{-5}$ & $\left.\mathrm{I} \cdot 8 \times \mathrm{IO}^{-4}\right\}$ & \\
\hline
\end{tabular}

The donor strains were SA $534 \mathrm{HfrK}_{4}$ (order of transfer: leu-pro-purE) and a $\mathrm{r}_{\mathrm{LT}}^{-} \mathrm{m}_{\mathbf{L T}}^{-}$derivative of it. Exponentially growing cultures of the donor strains were diluted $\mathrm{I} / \mathrm{I} 0$ into prewarmed broth and mixed with equal volumes of exponentially growing cultures of the recipient strains. The mixtures were centrifuged and placed at $37^{\circ}$ in a water bath, without resuspending the pellets. After $60 \mathrm{~min}$. the mixtures were shaken vigorously, diluted and plated on selective media. All selections were made in the presence of streptomycin $100 \mu \mathrm{g}$. $/ \mathrm{ml}$, to which only the donors were sensitive. The donor input was estimated from the colony count on nutrient agar plates seeded with diluted samples of the donor cultures at the start of the matings.

$\left.\mathbf{r}_{\mathrm{LT}}^{-} \mathrm{m}_{\mathrm{LT}}^{-} \times \mathrm{F}^{-} \mathrm{r}_{\mathrm{LT}}^{+} \mathrm{m}_{\mathrm{LT}}^{+}\right)$. The degree of restriction was estimated from the difference in the frequency of recombinants obtained between the two crosses in which $\mathrm{r}_{\mathrm{LT}}^{+} \mathrm{m}_{\mathrm{LT}}^{+}$ and $\mathrm{r}_{\mathrm{LT}}^{-} \mathrm{m}_{\mathrm{LT}}^{-}$donors were mated with the same $\mathrm{r}_{\mathrm{LT}}^{+} \mathrm{m}_{\mathrm{LT}}^{+}$recipient strain. Errors resulting from possible variations in fertility between individual donor cultures were corrected 
for from the difference in the number of recombinants for a given marker obtained in two control crosses in which the same two donor cultures were mated with a single non-restricting recipient strain. The number of recombinants in $\mathrm{Hfr}_{\mathrm{LT}}^{-} \mathrm{m}_{\mathrm{LT}}^{-} \times$ $F^{-} r_{L T}^{+} m_{L T}^{+}$crosses was clearly decreased as compared to the yield of the control crosses (Table 3).

The same kind of experiments were performed to assess the restriction of F-lac. F-lac ${ }^{+}$donors were obtained in LT 2 and LT $2 \mathrm{r}_{\mathrm{LT}}^{-} \mathrm{m}_{\mathrm{LT}}^{-}$after mating with Escherichia coli K I2 WI655 F-lac ${ }^{+}$. Strain WI655 F-lac ${ }^{+}$was also used as donor and restrictiondeficient mutants of $E$. coli $\mathrm{K} \mathrm{I} 2$ and B were included among the recipients. The yield of $\mathrm{lac}^{+}$clones was decreased about I00-fold in those crosses in which restriction could be exercised (Table 4 ). In the absence of restriction, transfer of F-lac ${ }^{+}$is not more effective between LT 2 strains than between $E$. coli and LT 2. It appears also that restriction-deficient mutants of $E$. coli are even better recipients for F-lac ${ }^{+}$transferred from LT 2 than LT 2 itself.

\section{Table 4. Host restriction of an F-lac ${ }^{+}$factor in Salmonella typhimurium and Escherichia coli}

Recipient strain

S. typhimurium

\section{proC 90 \\ proC $90 \mathrm{r}_{\mathrm{LT}}^{-} \mathrm{m}_{\overline{\mathrm{LT}}}$}

SL 1027

SL $1027 \mathrm{r}_{\mathrm{LT}}^{-} \mathrm{m}_{\mathrm{LT}}^{-}$

E. coli

B 25 I $\mathrm{r}_{\mathrm{B}}^{-} \mathrm{m}_{\mathrm{B}}^{-}$

C $600 \mathrm{r}_{\mathrm{K}}^{-} \mathrm{m}_{\mathrm{K}}^{-}$
No. of $\mathrm{lac}^{+}$clones per F-lac ${ }^{+}$donor

$\begin{array}{cc}\text { WI655 F-lac }^{+} & \text {LT2 F-lac } \\ 6.4 \times 10^{-7} & 8.5 \times 10^{-5} \\ 2.1 \times 10^{-4} & 1.6 \times 10^{-4} \\ 3.2 \times 10^{-7} & 2.7 \times 10^{-4} \\ 1 \cdot 3 \times 10^{-4} & 2.7 \times 10^{-4} \\ & \\ - & 4.4 \times 10^{-4} \\ - & 8.5 \times 10^{-4}\end{array}$

Corrected restriction value

$6 \cdot 2 \times 10^{-2}$

$\left.\begin{array}{l}4.1 \times 10^{-6} \\ 2 \cdot 1 \times 10^{-4}\end{array}\right\}$

$\mathrm{I} \cdot 2 \times 10^{-2}$

$1 \cdot 2 \times 10^{-2}$

Procedure as in Table 3, except that the male input was measured by plating samples of the donor on EMB lactose medium to exclude the lac segregants.

Table 5. Host restriction in P 22-mediated transduction of Salmonella typhimurium

\begin{tabular}{|c|c|c|c|c|}
\hline \multirow{2}{*}{$\begin{array}{l}\text { Recipient } \\
\text { strain }\end{array}$} & \multirow{2}{*}{$\begin{array}{l}\text { Selected } \\
\text { marker }\end{array}$} & \multicolumn{2}{|c|}{$\begin{array}{l}\text { No. of transductants per } \text { Io }^{10} \\
\text { plaque-forming units }\end{array}$} & \multirow{2}{*}{$\begin{array}{l}\text { Corrected } \\
\text { restriction } \\
\text { value }\end{array}$} \\
\hline & & $\mathrm{P} 22 . \mathrm{LT}$ & P 22.0 & \\
\hline $\begin{array}{l}\text { proC } 90 \\
\text { proC } 90 \mathrm{r}_{\mathbf{L T}}^{-\mathrm{m}_{\mathbf{L T}}}\end{array}$ & $\begin{array}{l}\text { proc } \\
\text { proc } \\
+\end{array}$ & $\begin{array}{l}3.9 \times 10^{4} \\
4.5 \times 10^{4}\end{array}$ & $\begin{array}{l}3.0 \times 10^{2} \\
2.0 \times 10^{4}\end{array}$ & $3.0 \times 10^{-3}$ \\
\hline $\begin{array}{l}\text { proC I Io } \\
\text { proC I IO } \mathrm{r}_{\mathrm{LT}}^{-} \mathrm{m}_{\mathrm{LT}}^{-}\end{array}$ & $\begin{array}{l}\operatorname{proC}^{+} \\
\text {proC }^{+}\end{array}$ & $\begin{array}{l}9.8 \times 10^{4} \\
4.9 \times 10^{4}\end{array}$ & $\begin{array}{l}5.4 \times 10^{2} \\
4.2 \times 10^{4}\end{array}$ & $4.6 \times 10^{-3}$ \\
\hline $\begin{array}{l}\text { SB I06 } \\
\text { SB I06 } \mathrm{r}_{L_{T} T^{-} m_{L T}^{+}}^{+}\end{array}$ & $\begin{array}{l}\text { proA } A^{+} \\
\text {proA } A^{+}\end{array}$ & $\begin{array}{l}4.8 \times 10^{3} \\
5 \cdot 0 \times 10^{3}\end{array}$ & $\begin{array}{l}2.2 \times 10^{2} \\
5.5 \times 10^{3}\end{array}$ & $5 \cdot 1 \times 10^{-2}$ \\
\hline $\begin{array}{l}\text { SA I } 95 \\
\text { SA } 195 \mathrm{r}_{\overline{\mathrm{LT}}}^{-} \mathrm{m}_{\mathrm{LT}}^{-}\end{array}$ & $\begin{array}{l}\text { purE } E^{+} \\
\text {purE } E^{+}\end{array}$ & $\begin{array}{l}\mathrm{I} \cdot 2 \times 10^{5} \\
\mathrm{I} \cdot 0 \times 10^{5}\end{array}$ & $\begin{array}{l}1 \cdot 4 \times 10^{2} \\
3.4 \times 10^{4}\end{array}$ & $4 \cdot \mathrm{I} \times 1 \mathrm{IO}^{-3}$ \\
\hline $\begin{array}{l}\text { SL } 1027 \\
\text { SL } 1027 \mathrm{r}_{\overline{\mathrm{LT} T}}^{-} \mathrm{m}_{\mathrm{LT}}^{-}\end{array}$ & $\begin{array}{l}\operatorname{trp} B^{+} \\
\operatorname{trp} B^{+}\end{array}$ & $\begin{array}{l}7 \cdot 3 \times 10^{3} \\
6 \cdot 2 \times 10^{3}\end{array}$ & $\begin{array}{l}1 \cdot 3 \times 10^{1} \\
3.8 \times 10^{3}\end{array}$ & $I \cdot I \times 10^{-3}$ \\
\hline
\end{tabular}

$\mathrm{P} 22$ lysates containing about $\mathrm{I} \times \mathrm{IO}^{11}$ plaque-forming $\mathrm{u}$. $/ \mathrm{ml}$. were obtained by the agar layer method on prototrophic $\mathrm{LT} 7$ and $\mathrm{LT} 7 \mathrm{r}_{\mathrm{LT}}^{-} \mathrm{m}_{\overline{\mathrm{LT}}}^{-}$strains. Exponentially growing cultures of the recipient strains were centrifuged and the deposit suspended in buffer at about $1 \times 10^{9}$ cells $/ \mathrm{ml}$. $1 \times 10^{10} \quad P_{22}$ particles were added to the suspensions and kept for $15 \mathrm{~min}$. at room temperature before plating on selective media. 
A similar set of experiments, in which the frequency of transduction was measured for several markers with P 22.LT and P 22.0 lysates in $r_{\mathrm{LT}}^{+}$and $r_{\mathrm{LT}}^{-}$strains showed that the degree of restriction for bacterial markers in transduction was about 100 -fold (Table 5).

\section{DISCUSSION}

The isolation and phenotypic characterization of a set of 48 restriction-deficient mutants in Salmonella typhimurium LT 2 clearly shows that the genetic control of host specificity in $S$. typhimurium is similar to other host specificity systems that have been studied. Similar types of mutants have been obtained in phage P I (Glover, Schell, Symonds \& Stacey, I963), in an extensive analysis in Escherichia coli $\mathrm{K}$ I 2 and B (Wood, 1966) and in Pseudomonas aeruginosa (Rolfe \& Holloway, 1968). Host restriction in Salmonella typhimurium was found to affect the frequency of recombinants formed in bacterial matings, the frequency of transduction, and also the acceptance of plasmids, in accord with previous observations in E. coli (Boyer, 1964; Arber, 1964; Arber \& Morse, 1965; Copeland \& Bryson, 1966).

It seems therefore that similar mechanisms of control over the acceptance of foreign DNA might be widespread among bacteria and since many experiments involve the transfer of DNA between unrelated bacterial strains, such as those which investigate genetic homology between bacterial species and the possibility of plasmid transfer, in interpreting such experiments the role of host restriction should be borne in mind. A striking example of this was the fer mutation of Salmonella typhimurium which remained puzzling for some years until it was shown that fer mutants were restrictiondeficient (Colson \& Colson, 1967; Okada, Watanabe \& Miyake, 1968).

The genetic basis of the mutations which affect host specificity cannot be inferred directly from the observed phenotypes. In particular, the fact that a single mutation quite often affects both restriction and modification remained unexplained until recently. Progress in understanding the mechanism of host specificity was achieved when it was shown that restriction and modification activities are exercised at particular sites on the DNA, which can be rendered an inadequate substrate for both activities by mutation (Arber \& Kühnlein, 1967). Recombination and complementation studies lead to the demonstration of a third cistron in addition to restriction and modification (Glover, I968; Glover \& Colson, 1969; Arber \& Linn, 1969). Mutations which affect host specificity can therefore occur in any one of at least three genes for which the symbols $h s s, h s r$ and $h s m$ have been recently proposed (Arber \& Linn, I969). It is likely that among the mutants described in the present paper, those with an $\mathrm{r}_{\mathrm{LT}}^{-} \mathrm{m}_{\mathrm{LT}}^{+}$phenotype lack the restriction function $(h s r)$ while those with an $\mathrm{r}_{\mathrm{LT}}^{-} \mathrm{m}_{\mathrm{LT}}^{-}$ phenotype are deficient in the recognition of the sites (hss). A possible explanation for the $\mathrm{r}_{\mathrm{LT}}^{-} \mathrm{m}_{\mathrm{LT}}^{ \pm}$phenotype is a mutation in the hss gene resulting in a lowered affinity for the host specific sites on the DNA. At first sight it would appear that such mutations should affect the degrees of restriction and modification equally, but it must be pointed out that the assay systems for restriction and modification are not equally sensitive. In assaying restriction of $\mathbf{P} 22.0$ as much as $20 \%$ of the phage could be restricted and remain undetected as a significant change in efficiency of plating, while in assaying modification as little as $0.1 \%$ modified phage in a lysate can easily be detected.

In view of the extensive homology between the genetic maps of Escherichia coli and Salmonella typhimurium (Sanderson \& Demerec, 1965) and the similarity between the 
host specificity system investigated here and those of $E$. coli, it is attractive to think that host specificity in $S$. typhimurium may belong to the allelic series of host specificities that are found in $E$. coli and which map close to thr. (Boyer, I964; Colson et al. 1965; Glover \& Colson, 1969). Experiments to be published will show that this $S$. typhimurium host-specificity system has quite a different chromosomal location close to the pro region.

\section{REFERENCES}

ARBER, W. (1964). Host specificity of DNA produced by Escherichia coli. III. Effects on transduction mediated by $\lambda d g$. Virology $\mathbf{2 3}, 173$.

Arber, W. \& KüHNLein, U. (1967). Mutationeller Verlust B-spezifische Restriktion des Bacteriophagen fd. Pathologia Microbiol. 30, 946.

Arber, W. \& Linn, S. (1969). DNA modification and restriction. A. Rev. Biochem. 8 (in the Press).

Arber, W. \& Morse, M. L. (I965). Host specificity of DNA produced by Escherichia coli. VI. Effects on bacterial conjugation. Genetics, Princeton 5I, 137.

ARber, W. \& Smith, J. D. (I966). Host-controlled modification of phage fd and its correlation with specific methylation of desoxyribonucleotides. IXth Int. Congr. Microbiol., p. 5.

BOYER, H. (1964). Genetic control of restriction and modification in Escherichia coli. J. Bact. 88, I652.

Colson, C. \& Colson, A. M. (1967). Host specificity and fertility in Salmonella typhimurium LT 7. Biochem. biophys. Res. Commun. 29, 692.

Colson, C., Glover, S. W., Symonds, N. \& Stacey, K. A. (1965). The location of the genes for host-controlled modification and restriction in Escherichia coli K-I2. Genetics, Princeton 52, 1043.

Copeland, J. C. \& BRYSON, V. (I966). Restriction in matings of Escherichia coli strain K-I2 with strain B. Genetics, Princeton 54, $44 \mathrm{I}$.

Glover, S. W. (1968). Host specificity in $\mathrm{F}^{\prime}$ heterogenotes of Escherichia coli. J. gen. Microbiol. $\mathbf{5 3}, \mathrm{i}$.

Glover, S. W. \& Colson, C. (1969). Genetics of host-controlled restriction and modification in Escherichia coli. Genet. Res. 13, 227.

Glover, S. W., Schell, J., Symonds, N. \& Stacey, K. A. (I963). The control of host-induced modification by phage P I. Genet Res. 4, 480 .

Mesel.son, M. \& YUAN, R. (I968). DNA restriction enzyme from E. coli. Nature, Lond. 217, i I 10.

MrYake, T. (1962). Exchange of genetic material between Salmonella typhimurium and Escherichia coli K-I 2. Genetics, Princeton 47, 1043.

OKaDA, M. \& WATANABE, T. (1968). Isolation of Salmonella typhimurium mutants with increased recipient ability by the use of $\mathrm{R}$ factor. Nature, Lond. $\mathbf{2 1 7}, 854$.

Okada, M., Watanabe, T. \& MiYake, T. (I968). On the nature of the recipient ability of Salmonella typhimurium for foreign deoxyribonucleic acids. J. gen. Microbiol. 50, 24I.

Rolfe, B. \& Holloway, B. W. (1968). Genetic control of DNA specificity in Pseudomonas aeruginosa. Genet. Res. 12, 99.

Sanderson, K. E. \& Demerec, M. (I965). The linkage map of Salmonella typhimurium. Genetics, Princeton 5I, 897.

SMITH, H. O. (1968). Defective phage formation by lysogens of integration deficient phage P 22 mutants. Virology 34, 203.

Smith, H. O. \& Levine, M. (1967). A phage P 22 gene controlling integration of prophage. Virology 3I, 207.

Wood, W. B. (1966). Host specificity of DNA produced by Escherichia coli: bacterial mutations affecting the restriction and modification of DNA. J. molec. Biol. 16, I 8.

ZINDER, N. D. (1960). Hybrids of Escherichia and Salmonella. Science, N.Y. 13r, 8I3. 